\title{
Fair Value Accounting: A Controversial but Promising System
}

\author{
Fawzi A. Al Sawalqa ${ }^{1}$ \\ ${ }^{1}$ Dean of Business Faculty /Accounting Department/ Tafila Technical University, P. O. Box 179, Tafila 66110, \\ Jordan
}

Correspondence: Fawzi A. Al Sawalqa, Dean of Business Faculty /Accounting Department/ Tafila Technical University, P. O. Box 179, Tafila 66110, Jordan. Tel: 962-77-228-2190.

Received: November 24, 2015

Accepted: December 21, $2015 \quad$ Online Published: December 22, 2015

doi:10.5430/afr.v5n1p88

URL: http://dx.doi.org/10.5430/afr.v5n1p88

\begin{abstract}
There is almost a worldwide consensus that the usage of fair value accounting is not an easy task due to a number of limitations that affect its reliability. Prior studies in fair value accounting have unanimously agreed on the existence of clear defects in measuring fair value, especially under level 3 of fair value hierarchy where the active market does not easily exist for the asset or liability. Based on previous literature in the field, the current study discusses the reasons for the ongoing debate on the reliability of fair value accounting and also suggests some relevant procedures to enhance fair value accounting system. In particular, the paper offers some creative suggestions that standard-setters (e.g. FASB and IASB), regulators, practitioners and academics should globally adopt to ensure a brighter future for fair value accounting. In addition, the paper provides a set of the necessary future research avenues in fair value and the related accounting standards.
\end{abstract}

Keywords: Fair value accounting, Fair value hierarchy, Active market, FASB, IASB

\section{Introduction}

The idea of fair value accounting is not a new one (Power, 2010; Guthrie, Irving \& Sokolowsky, 2011) and comes mainly to overcome the limitations of historical cost accounting (e.g. Carroll, Linsmeier \& Petroni, 2003; Laux \& Leuz, 2009; Power, 2010; Devi, Devi, Kumar \& Taylor, 2012; Barth, 2014; Betakova, Hrazdilova-bockova \& Skoda, 2014; Taplin, Yuan \& Brown, 2014). (Note 1) The main purpose of fair value accounting is to identify the actual market value of an asset or liability at the measurement date (Milburn, 2008) and to overcome the limitations of historical cost accounting in measuring the actual value of an asset or liability subsequent to acquisition date, especially in case of impairment (Linsmeier, 2013). That is, fair value accounting comes to give a fair value to entity under current market conditions (Pabuccu, 2011). Thus, it can be argued that fair value accounting is now an important dominant system (e.g. Hitz, 2007; Wier, 2009; Jaggi, Winder \& Lee, 2010 ; Liao, Liu, Suvankulov \& Branson, 2014; Yamamoto, 2014) used to a considerable extent by listed companies in all over the world (Taplin, Yuan \& Brown, 2014) and created a lot of controversy and debate among interested parties (Bell \& Griffin, 2012; Kaytmaz Balsari \& Varan, 2014) due to existence of some difficulties in its implementation process, especially as a balance sheet measure (Hitz, 2007) and due to its supposed role in the international financial crisis of 2007-2009 (Procházka, 2011; Betakova, Hrazdilova-Bockova \& Skoda, 2014; Markarian, 2014).

Both SFAS 157 and SFAS 159 defined fair value as, "the price that would be received to sell an asset or paid to transfer a liability in an orderly transaction between market participants at the measurement date" (FASB, 2006, SFAS 157, para.5; FASB, 2007, SFAS 159, para.6). Fornaro and Barbera (2007, p.31) commented on this definition by stating that, " fair value measurements reflect assumptions that knowledgeable, independent market participants would make to hypothetically price the asset or liability, as opposed to relying on management's internal or entity-specific assumptions". Researchers such Hitz (2007, p. 326) defined fair value as, "the exit market price that would result under close-to-ideal market conditions, in a transaction between knowledgeable, independent and economically rational parties, which interact on the basis of an identical information set (complete information)". Thus, to accurately measure the fair value, a set of factors should be met. The scarcity of presence such factors at once may create challenge to companies to measure their assets and liabilities in an accurate way. In addition, the efficiency of fair value depends mainly on the types of markets in which assets or liabilities are found. This, however, has created an ongoing debate (e.g. Laux \& Leuz, 2009; Jaggi, Winder \& Lee, 2010) in business markets over the reliability of fair value. This debate led to two consequences depending on the place of 
implementation. In developed countries, where the active markets are available, scholars and decision-makers have made exceptional efforts to limit the deficiencies in fair value measurement process. In developing countries, where the active markets are not easily available, the debate has been continued. Thus, it can be argued that many implementation problems in fair value accounting are still outstanding; especially in developing countries.The justification of such pessimistic view is built on several facts. Firstly, the lack of the studies that addresses the fair value accounting as a new necessity in accounting profession in such countries. Secondly, the lack of focus on the fair value in the universities' accounting curricula. Thirdly, the ambiguity in the accounting standards that presents fair value accounting. Fourthly, the complexity in the rules and instructions that are necessary to apply fair value accounting. Fifthly, the availability of the historical cost accounting system, which is an easier and a more stable alternative than the fair value accounting. Finally, the lack of business markets that are suitable to apply fair value accounting.

Hitz (2007, p. 325) states that "theoretical research so far has been relatively silent on the properties and desirability of fair value measurement". This is totally true with the third world countries. In addition, the vagueness and difficulty of fair value system justify the scarcity of studies in fair value accounting in those countries. Accordingly, the current study comes as an attempt to fill the gap in prior research, especially in the developing countries, where the implementation of fair value accounting faces several problems.

Based on previous research in fair value accounting, the current study employed the theoretical approach to identify and discuss the reasons behind the ongoing debate on the reliability of fair value accounting and mainly to offer some suggestions to enhance the reliability of fair value accounting in all over the world with special focus on emerging markets.

The next section reviews fair value accounting with some emphasis on its measurement methods. Section three discusses the limitations of fair value accounting. Section four sheds some light on some strength aspects of fair value accounting as a promising system. Section five concludes the paper. Finally, section six offers the necessary recommendations to improve fair value accounting system.

\section{Overview of Fair Value Accounting system}

Prior to the presentation of the Statement of Financial Accounting Standards (SFAS) 159 "The Fair Value Option for Financial Assets and Financial Liabilities" (FASB, 2007), the Financial Accounting Standard Board (FASB) issued three fair value accounting statements (i.e. SFAS No. 107 in 1991, SFAS No. 115 in 1993 and SFAS No.133 in 1998) which have played an important role in appearance of SFAS 159 (Guthrie, Irving \& Sokolowsky, 2011).

In 2006, FASB issued SFAS 157 "Fair Value Measurements" (FASB, 2006). According to Wallison (2008), SFAS 157 requires firms to give more attention to market prices by introducing three levels to classify the assets and liabilities that recognised at fair value (see, for example, Fornaro \& Barbera, 2007; Miller \& Bahnson, 2007; Wallison, 2008; Guthrie et al., 2011; Devi et al., 2012; Ronen, 2012; Betakova, Hrazdilova-bockova \& Skoda, 2014; Singh, 2015). Level 1 represents the quoted prices of quite similar or identical assets or liabilities in active or liquid markets at the selected measurement date (FASB, 2006, SFAS 157, para. 24). (Note 2) Level 2 represents the quoted prices of elements other than those of level 1 and are observable directly or indirectly (FASB, 2006, SFAS 157, para. 28). (Note 3) Level 3 depends on unobservable inputs that estimated subjectively to determine the price of assets or liabilities (FASB, 2006, SFAS 157, para. 30). (Note 4) To measure the fair value of the asset or liability, three approaches are available including income approach, cost approach and market approach. FASB (2006, SFAS 157, para. 18) identifies the base for each approach, in that market approach depends on the information collected from the market to determine the fair value of the element, income approach focuses mainly on discounting the future outcomes of the element to its present values depending on some current market indicators, while cost approach depends on the current replacement cost of the element to determine its fair value. (Note 5)

FASB 157 has been criticized in several aspects, such as the lack of active markets and the lack of orderly transactions (FASB, 2009). Accordingly, in April 2009 some amendments to SFAS 157 have been taken place through FAS 157-4. According to Jaggi, Winder and Lee (2010, p. 491) the amendments give entities the opportunity to select the proper measurement method to identify the fair value. In particular, FAS 157-4 introduced some amendments to FASB 157 to simplify the measurement of fair value, especially, "when the volume and level of activity for the asset or liability have significantly decreased when compared with normal market activity for the asset or Liability (or similar assets or liabilities)" (FASB, 2009, FSP FAS 157-4, para. 9, p. 3). However, FAS 157-4 listed the factors that an entity should evaluate to determine the decrease in the level and volume of an element (see, FASB, 2009, FSP FAS 157-4, para. 12, p. 3-4) and to determine if the transaction is orderly or not (see, FASB, 2009, FSP FAS 157-4, para. 17, p. 7) taking in account the risk premium that should be included in the selected fair value 
measurement method (FASB, 2009). Despite these modifications, the debate on the reliability of fair value accounting has not finished yet (Laux \& Leuz, 2009; Jaggi, Winder \& Lee, 2010).

In February 2007, the FASB presented SFAS No. 159 "The Fair Value Option for Financial Assets and Financial Liabilities" (FASB, 2007). In the first two paragraphs of SFAS 159, FASB (2007) identified the main objectives of the statement. These include, firstly; expansion the scope of items that could be measured at fair value (FASB, 2007, SFAS 159, para. 1). According to Guthrie et al. (2011, p. 490) eligible items include, for example, "available-for-sale securities and mortgage loans held for sale", while ineligible items include "pension and post-retirement liabilities, lease assets and liabilities, and deposit liabilities". Secondly, SFAS 159 also creates the necessary procedures to enhance the comparability between those entities that measure similar elements differently (FASB, 2007, SFAS 159, para. 2). However, SFAS 159 keeps the disclosure requirements of SFAS 157 "Fair Value Measurements" and SFAS 107 "Disclosures about Fair Value of Financial Instruments" (FASB, 2007, SFAS 159, para. 2, p.1).

Recently, the International Accounting Standard Board (IASB) presents the International Financial Reporting Standard (IFRS) 13 "Fair Value Measurement" (see, for example, Betakova, Hrazdilova-Bockova \& Skoda, 2014) which offers some rules and instructions to facilitate the measurement process of fair value (Palea \& Maino, 2013). However, IFRS 13 needs more investigation in future research.

The next section discusses some of the deficiencies of fair value accounting along with the potential consequences of such deficiencies.

\section{Fair Value Accounting as A controversy System}

It has been argued that fair value accounting is complex and ambiguous system, which led to obvious problems in the actual implementation (e.g. Barth \& Landsman, 1995; Carroll, Linsmeier \& Petroni, 2003; Ball, 2006; Karstetter \& Lien, 2009; Rabin, 2009; Badertscher, Burks \& Easton, 2012; He, Wong \& Young, 2012; Hlaing \& Pourjalali, 2012; Cristin \& Miticã, 2013; Kaya, 2013; Taplin, Yuan \& Brown, 2014). Such complexity and ambiguity have built on the fact that fair value is only found in the active markets which encouraged entities to put more emphasis on estimation approach to identify the fair value of the asset or liability (Barth \& Landsman, 1995). This procedure, however, affects the harmonization of accounting practices among countries and delays the convergence between IFRS and local standards of some countries (e.g. Taplin, Yuan \& Brown, 2014).

Much debate has also been taken place recently among the practitioners and other interested parties over the efficiency of fair value due to international financial crisis. Thus, numerous prior studies (e.g. Laux \& Leuz, 2010; Pabuccu, 2011; Procházka, 2011; Badertscher, Burks \& Easton, 2012; Kaya, 2013; Betakova, Hrazdilova-bockova \& Skoda, 2014; de Jager, 2014; Markarian, 2014) have discussed the role of fair value in international financial crisis. For example, when the financial crisis occurred in 2008, some banks reclassified their financial assets in order to avoid recognizing the losses that resulted from fair value pricing after adopting IAS 39 "Financial Instruments: Recognition and Measurement" and IFRS 7 "Financial Instrument: Disclosures" (Mănoiu \& Damian, 2015, p. 94). (Note 6) Betakova, Hrazdilova-Bockova and Skoda (2014) justify the contribution of fair value to financial crisis on the basis that fair value usually depends on specific market conditions that any change in may cause real problem. However, one important issue that incorporated fair value in international financial crisis according to Procházka (2011) is the distribution of unrealized profit as dividends by some entities due to the change in the market prices of assets at the end of financial period, which led to erosion of capital (see also, Jaggi, Winder \& Lee, 2010). Another important issue according to Laux and Leuz (2010) is that fair value accounting encouraged financial organizations to increase their leverage in economic prosperity periods and forced such entities to sell their assets at lower prices due to huge impairment in economic downturn periods, which also led to erosion of capital. In general, Laux and Leuz (2010) conclude that fair value only slightly contributed to the financial crisis.

It has been argued that fair value is not well defined as it is difficult for all or some important factors (e.g. volume, frequency) to be met once (Landsman, 2007). Another argument on the lack of complete definition for fair value that may affect the comparability of financial statements according to Procházka (2011) is that a particular element may be measured in one entity using fair value and historical cost in another, as well as identifying the fair value of the asset or liability in some circumstances depends on entity's own assumptions, which means several fair values may be found for one element at one time (see also, Lilien, Sarath \& Schrader, 2013; Alves de Souza et al., 2015).

The three levels of fair value hierarchy contain ambiguous details that make it difficult to measure fair value effectively. Thus, many studies have questioned the reliability of fair value accounting and strongly criticized the ambiguity of its hierarchy, especially level 2 and level 3 where the active market is not found in practice (see, for 
example, Landsman, 2007; Badertscher, Burks \& Easton, 2012; Hlaing \& Pourjalali, 2012; Ronen, 2012; Kaya, 2013). (Note 7) That is, the measurement of fair value is not an easy task, which makes it difficult to ensure its accuracy (e.g. Barth \& Landsman, 1995; Landsman, 2007; Kaytmaz Balsari \& Varan, 2014; Liao et al., 2014). In this context, Ball (2006) criticized the fair value accounting in the basis that it, in some circumstances, not represents the actual market price and in others can be easily manipulated (see, for example, Jordan, Clark \& Pate, 2013). Landsman (2007) argued that the scarcity of presence the active market in practice means that fair value of the asset or liability will be measured based on level 2 or level 3 of fair value hierarchy, which creates difficulty to ensure its accuracy as these two levels are subject to the subjective estimation by management. Similarly, Ronen (2008) criticized level 2 and level 3 in particular as it gives the opportunity to entity's management to subjectively estimate unobservable inputs to identify fair value of an element. Such estimation according to Ronen (2008) includes errors that may distort balance sheet and income statement. In the same context, and particularly for financial assets, Strampelli $(2011$, p. 4) argued that fair value is not suitable to measure the actual market value of financial assets in case of illiquid markets. Ronen (2012) criticized level 2 and level 3 of fair value hierarchy, as described in SFAS 157, in the basis that identifying the fair value of the asset or liability based on level 2 is very difficult task as any mistake in observed inputs or estimated value of asset or liability may lead to a serious trouble in financial statements. According to Ronen (2012) the problem is more complex if level 3 is used to determine the fair value of the asset or liability as the measurement process, in this case, depends on unobservable inputs subject to the management subjective decisions. In addition, Ronen (2012) outlined the risks associated with the exit values of financial instruments mainly when the optimal conditions are not met once in case of illiquid markets. (Note 8) Kaya (2013) argued that fair value suffers many limitations and deficiencies, especially in respect of level 3 of fair value hierarchy, which depends mainly on unobservable inputs identified subjectively by the entity. Bratten et al. (2013) criticized level 2 and mainly level 3 of fair value hierarchy as it needs subjective judgments that lead to uncertainty or error in measurement of fair value. This, however, bears auditors additional responsibilities to ensure the validity of the recognition value for the asset or liability (e.g. Ronen, 2008; Bell \& Griffin, 2012; Lilien, Sarath \& Schrader, 2013). According to Valencia, Smith and Ang (2013) the possible errors in measurement of fair value of financial elements have contributed to the collapse of many banks lately. Betakova, Hrazdilova-Bockova and Skoda (2014) indicated that the measurement process of fair value accounting is ambiguous, which may misrepresent the actual market price of the asset or liability. In addition, Betakova, Hrazdilova-Bockova and Skoda (2014) argued that fair value is subject to manipulation and is only occasionally reliable as it depends on specific market conditions (see, for example, Hitz, 2007; Milburn, 2008; Laghi et al., 2012). Therefore, some institutional factors such as government regulations and political pressure may force companies to put more emphasis on managing its earnings rather than implementing the rules of fair value accounting (e.g. Bonaci \& Strouhal, 2011; He, Wong \& Young, 2012; Bratten et al., 2013; Cristin \& Miticã, 2013; Lilien, Sarath \& Schrader, 2013).

Despite the doubt in the reliability of level 2 and level 3 of fair value hierarchy, findings by Leggett, Wilkins and Clark (2015) indicated that there is a growing tendency to use such levels to value liabilities for example. Accordingly, more and more efforts are needed to enhance the reliability of fair value under level 2 and level 3 of fair value hierarchy.

However, the above discussions reveal that the current fair value system suffers some limitations due to its ambiguity and complexity at the first instance. But this does not minimize the ability of fair value accounting, in some circumstances, to measure the actual value of the entity efficiently as shown in the next section.

\section{Fair Value as A promising Accounting System}

Although there are problems in the implementation process of fair value accounting, it could be argued that additional efforts by accounting standard- setters (e.g. FASB and IASB), regulators, practitioners and academics will enhance its reliability. Despite that prior studies have shown mixed results in the relevance of fair value accounting over historical cost accounting (Hitz, 2007), it has been argued that fair value accounting is almost better than historical cost accounting, which includes some rooted limitations (Laux \& Leuz, 2009) that may be removed by using both systems (e.g. Jordan, Clark \& Pate, 2013; Betakova, Hrazdilova-Bockova \& Skoda, 2014). According to Fornaro and Barbera (2007), for fair value accounting to be useful, it should be almost in line with the contents of Statement of Financial Accounting Concepts No.2 "Qualitative Characteristics of Accounting Information" (FASB, 1980, CON 2). In this context, Evans, Hodder and Hopkins (2014) findings indicated that fair value information has the ability to predict some of the future outcomes of banks for example. However, it has been argued that fair value accounting is more relevant for different types of decisions than historical cost accounting as it reflects the current market value of the element at a point of time (e.g. Jordan, Clark \& Pate, 2013), but historical cost accounting is more reliable as it depends on observable data at the date of acquisition (Linsmeier, 2013). According to Betakova, 
Hrazdilova-Bockova and Skoda (2014), fair value accounting uses up-to-date information to measure the value of the asset or liability and discloses more information than historical cost accounting. On the other hand, Betakova, Hrazdilova-Bockova and Skoda (2014) indicated that fair value accounting has also many limitations that can be avoided with time (see also, Markarian, 2014). However, according to Singh (2015) fair value accounting has the ability to show the actual value of entity if it is implemented carefully. Singh (2015) has pointed out to the role of auditors, for example, in ensuring the proper implementation of fair value system (see also, Ronen, 2008; Bratten et al., 2013; Lilien, Sarath \& Schrader, 2013).

However, one of the features of fair value accounting is that it has a close relationship with different accounting standards. Early, Barth and Landsman (1995) indicated that many standards were focused on using fair value accounting to recognize assets and liabilities (see also, Landsman, 2007). In the same context, Ball (2006, p.12) pointed out to the existence of relationship with other standards such as "IAS 16, IAS 36, IAS 38, IAS 39, IAS 40, IFRS 2 and IFRS 3". However, fair value has also its place in IFRS 4, IFRS 5, IFRS 7, IFRS 9, IFRS 10 and IFRS 13. According to Miller and Bahnson (2007) one of the main advantages of SFAS 157 is that it contributes in amending and creating several standards necessary to enhance the reliability of fair value accounting. Landsman (2007, p. 20-21) shows a set of SFASs "SFAS 119, SFAS 107, SFAS 115, SFAS 123, SFAS 133" and IASs/IFRSs "IAS 32, IAS 39 , IFRS 2, IFRS 7" that contribute in using fair value to recognize different types of assets and liabilities.

Based on the above discussions, it can be argued that additional efforts are needed from interested parties to enhance the reliability of fair value accounting.

\section{Summary and Conclusion}

It can be argued that fair value accounting is a system created to value assets and liabilities based on a set of general rules depend on most of them on the ability of management in employing all the necessary creative efforts to identify the true value for the element under valuation. In particular, fair value accounting is a system used to recognize assets and liabilities in the balance sheet with the difference in the values of such elements transferred to income statement (Clor-Proell, Proell \& Warfield, 2014).

An extensive debate has been taken place in the prior studies about the reliability of fair value accounting. Based on the above discussion, the main reasons for such debate can be summarized in the following three topics:

\subsection{Measurement of Fair Value}

Previous studies (e.g. Landsman, 2007; Badertscher, Burks \& Easton, 2012; Ronen, 2012; Hlaing \& Pourjalali, 2012; Kaya, 2013) have strongly criticized the ambiguity of fair value hierarchy, especially level 2 and level 3 . These two levels encourage entities to subjectively estimate unobservable inputs (especially in level 3 ) to identify fair value of the asset or liability (e.g. Ronen, 2008; Ronen, 2012; Kaya; 2013). This, however, leads to two main problems according to prior research in the field:

1. Difficulty in ensuring the accuracy of fair value of the asset or liability (e.g. Barth \& Landsman, 1995; Landsman, 2007; Ronen, 2008; Bell \& Griffin, 2012; Bratten et al., 2013; Valencia, Smith \& Ang, 2013; Betakova, Hrazdilova-Bockova \& Skoda, 2014; Kaytmaz Balsari \& Varan, 2014; Liao et al., 2014). This, however, gives preference to historical cost accounting, which is more reliable than fair value accounting as it depends on clear evidences at the date of acquisition (Linsmeier, 2013; Smith \& Smith, 2014).

2. Facilitating the manipulation in the fair value of the element (e.g. Ball, 2006; Hitz, 2007; Milburn, 2008; Jordan, Clark \& Pate, 2013; Betakova, Hrazdilova-Bockova \& Skoda, 2014). This also gives preference to historical cost accounting over fair value accounting.

The direct consequence of the above two problems is the existence of several values for an element at the same time (e.g. Procházka, 2011; Lilien, Sarath \& Schrader, 2013; Alves de Souza et al., 2015). This, however, weakens the comparability among entities and damages the credibility of financial statements (Procházka, 2011).

\subsection{International Financial Crisis (2007-2009)}

An extensive debate has been taken place in previous research ( e.g. Laux \& Leuz, 2010; Pabuccu, 2011; Procházka, 2011; Badertscher, Burks \& Easton, 2012; Kaya, 2013; de Jager, 2014; Betakova, Hrazdilova-Bockova \& Skoda, 2014; Markarian, 2014) about the possible role of fair value accounting in the international financial crisis. The proposed role of fair value in international financial crisis was connected to the erosion of capitals in some financial organizations as a result of recognizing unrealized profits as dividends (e.g. Magnan, 2009; Jaggi, Winder \& Lee, 2010; Procházka, 2011) due to impairment of their assets (e.g. Laux \& Leuz, 2010; Procházka, 2011). 


\subsection{Decision-Making Process}

Despite the above mentioned limitations, it has been noted that fair value accounting is more relevant than historical cost accounting for decision-making process due to the following reasons:

1. Fair value accounting system has the ability to reflect the actual market price of element at the date of measurement (e.g. Milburn, 2008; Jordan, Clark \& Pate, 2013; Singh, 2015), especially in case of level 1 of fair value hierarchy, where active or liquid markets are the dominant.

2. Fair value accounting system gives more emphasis to disclosure of accounting information (e.g. Betakova, Hrazdilova-Bockova \& Skoda, 2014), especially in case of level 2 and mainly level 3, where active or liquid markets are absent.

However, the relevance of fair value for decision-making process collides with two main facts:

a. The availability of the active markets in practice is an exceptional phenomenon. This problem encourages entities to use level 2 and level 3 of fair value hierarchy, where the subjective valuation distorts the actual market price of element at the date of measurement (e.g. Landsman, 2007; Badertscher, Burks \& Easton, 2012; Ronen, 2012; Hlaing \& Pourjalali, 2012; Kaya, 2013). This problem is expected to mislead the decision-makers.

b. The disclosed accounting information that resulted from using level 2 and level 3 of fair value hierarchy is based on subjective estimation of entities' managements. This gives an indicator that such information is unreliable, and is not relevant enough for decision- making process.

The next section proposes some suggestions that may contribute in enhancing the future of fair value accounting.

\section{Recommendations for Improvement}

Despite all the above mentioned limitations, the fair value accounting could be a promising system. It has been noted from the above discussion that only level 1 of fair value hierarchy can measure the fair value of the asset or liability in a reliable way. Thus, most of the limitations of fair value accounting are centered in level 2 and particularly in level 3. Based on this fact, the current study offers a set of recommendation and suggestions that standard-setters (e.g. FASB and IASB), regulators, practitioners and academics should consider to enhance the reliability of fair value accounting:

1. Striving to enhance the transparency of accounting information by disclosing any uncertainty in the accuracy of the fair value of an element along with all procedures that have employed to validate such value, whether from the entity itself or by the auditors, especially in case of level 3 of fair value hierarchy (e.g. Bell \& Griffin, 2012; Leggett, Wilkins \& Clark, 2015).

2. Striving to limit uncertainty in financial markets by setting the necessary rules to value financial assets and financial liabilities in clear guidelines, especially under level 3 of fair value hierarchy (e.g. Jaggi, Winder \& Lee, 2010; Lilien, Sarath \& Schrader, 2013, Leggett, Wilkins \& Clark, 2015).

3. Striving to activate level 1 of fair value hierarchy widely by offering some technical solutions to make the data of the liquid markets available for illiquid ones. Despite that such procedure needs the liquid markets to disclose precise details about their activities; they can offer such information commercially through some specialized organizations or agents. This procedure will give entities in any country the opportunity to enter such active markets at any time to identify the fair value of their assets or liabilities based on the identical or similar elements.

4. Striving to set a timetable for using historical cost accounting by standard-setters. That is, it is rational to allow entities to use historical cost accounting as an acquisition model for only the next five years, for example, along with fair value accounting (e.g. Jordan, Clark \& Pate, 2013; Betakova, Hrazdilova-Bockova \& Skoda, 2014) as a measurement method subsequent to acquisition date. Identifying such dead line will give an important indicator to entities that the future will be only for fair value accounting to measure the value of different elements at any time during the financial year. This will encourage entities to modify their accounting systems along with their business environment to accommodate fair value accounting at a specific future point of time (e.g. Linsmeier, 2013).

5. Striving to improve the global business environment to be more appropriate for the active markets. This can be achieved by helping emerging markets to rearrange their markets to be more liberal. That is, developed countries may sign free trade agreements with developing countries to utilize available resources in such a manner to 
maximize their productivity. This, however, will help developing countries to acquire the Western business culture and will facilitate the accounting standards harmonization. This action is reasonable due to the fact that fair value accounting is already rooted in many accounting standards (e.g. Barth \& Landsman, 1995; Ball, 2006; Landsman, 2007).

6. Striving to amend the current international accounting standards to be easier for implementation. This will remove the current ambiguity in some standards where fair value accounting becomes an integral part of these standards. This can be achieved through activating the interpretation committees of accounting standards and increasing the instructions necessary to explain the implementation process of such standards. This can also be accomplished by selecting representatives from different countries to contribute in preparing appropriate standards for different types of markets.

7. Striving to amend the current accounting regulations (e.g. Jaggi, Winder \& Lee, 2010) in each country to accommodate the current international accounting standards. This will bridge the gap among different countries in the adoption degree of accounting standards and fair value accounting.

8. Striving to consider fair value accounting as a core course in all universities in all over the world with international accounting standard (IFRS/IAS) as a prerequisite course for it (see, for example, Beaudoin \& Hughes, 2014).

9. Striving to offer all the necessary training needs in fair value accounting and the related standards to all the interested parties (e.g. accountants and auditors). This mission can be arranged and performed by standard-setters, who have the ability to offer and explain any ambiguous issues in different standards.

10. Striving to build the bridges of cooperation between standard-setters and the institutions of certified public accountants in all over the world. This cooperation would improve the general understanding of accounting profession and will reform the requirements of various professional certifications in accounting to give more emphasis to fair value accounting.

The current study exceeds prior studies in fair value accounting field by offering some innovative suggestions to improve fair value accounting. Thus, this paper forms an important addition to the current knowledge in accounting. Despite that, the paper does not separate the financial assets from non-financial ones. Thus, future studies may perform independent studies for two types of assets. In addition and as a part of the current study recommendations to enhance fair value accounting, a set of future research avenues are also offered. These include:

1. Future project may investigate different FASB statements along with their amendments and IASB pronouncements that related to fair value accounting to identify their suitability to actual implementation. Such research may take both developed and emerging markets to perform the study.

2. Several institutional and political factors have played a significant role in selecting the accounting practices, especially in economic volatility periods (e.g. Bonaci \& Strouhal, 2011; He, Wong \& Young, 2012; Bratten et al., 2013; Cristin \& Miticã, 2013; Lilien, Sarath \& Schrader, 2013; Betakova, Hrazdilova-Bockova \& Skoda, 2014; Markarian, 2014). Future research may investigate the contribution of such factors in involving fair value accounting in international financial crisis by taking actual case studies from all over the world. Such study will be very important to prevent decision-makers, especially in financial entities to recur any previous mistakes.

3. Most of financial assets and liabilities that covered in SFAS 159 are estimated subjectively based on level 2 and level 3 of fair value hierarchy (Guthrie, Irving \& Sokolowsky, 2011). Future research opportunities may offer new models to enhance the valuation process of such elements using SFAS 115 and SFAS 157 (e.g. Wallison, 2008).

4. Those elements that have been estimated subjectively by entities' managements, need more efforts from auditors to verify their reliability (Bell \& Griffin, 2012; Singh, 2015). This is because recent evidence (Taplin, Yuan \& Brown, 2014) indicates that an association is found between fair value accounting and earning management (see also, Benston, 2006). Future study, for example, may propose the necessary procedures to control fair value audit risks and their role in hedging accounting (e.g. Săhlian, Botea \& Traşcă, 2013; Ronen, 2012). In addition, the future study may offer new disclosure approach for such elements to decrees uncertainty that surrounding their valuation process (Bell \& Griffin, 2012).

5. The corporate governance principles, especially in disclosure and transparency may give some solutions to the valuation of fair value under level 3of fair value hierarchy (e.g. Mănoiu \& Damian, 2015). Future research 
opportunity can perform in depth study to assess how entities can use corporate governance mechanisms to enhance the reliability of fair value accounting in context of recognition, reporting and disclosure.

6. One of the objectives of IFRS 13 is to facilitate the use of actual market prices in measuring fair value (Palea \& Maino, 2013). Future study may perform qualitative study to identify the contribution of IFRS 13 toward enhancing the measurement process of fair value, especially under level 3 of fair value hierarchy.

In addition to the above mentioned contributions of the current study, the recommendations outlined in this paper can be easily generalized globally as the fair value accounting is an international system spreads in all over the world. Thus, standard-setters, regulators, practitioners and academics in all over the world can use and build on the results and recommendations of the current study to enhance fair value accounting which is a promising system.

\section{References}

Alves de Souza, F. Ê., Alves Botinha, R., Silva, P. R., \& Lemes, S. (2015). Comparability of Accounting Choices in Future Valuation of Investment Properties: An Analysis of Brazilian and Portuguese Listed Companies. Revista Contabilidade \& Finanças - USP, 26(68), 154-166. http://dx.doi.org/10.1590/1808-057x201500580

Badertscher, B. A., Burks, J. J., \& Easton, P. D. (2012). A Convenient Scapegoat: Fair Value Accounting by Commercial Banks during the Financial Crisis. Accounting Review, 87(1), 59-90. http://dx.doi.org/10.2308/accr-10166

Ball, R. (2006). International Financial Reporting Standards (IFRS): pros and cons for investors. Accounting and Business Research, 36(sup1), 5-27. http://dx.doi.org/10.1080/00014788.2006.9730040

Barth, M. E. (2014). Measurement in Financial Reporting: The Need for Concepts. Accounting Horizons, 28(2), 331-352. http://dx.doi.org/10.2308/acch-50689

Barth, M. E., \& Landsman, W. R. (1995). Fundamental Issues Related to Using Fair Value Accounting for Financial Reporting. Accounting Horizons, 9(4), 97-107.

Beaudoin, C. A., \& Hughes, S. B. (2014). APT, Inc.: An Application of Impairment Testing and Fair Value Estimation Using International Financial Reporting Standards. Issues in Accounting Education, 29(1), 181-194. http://dx.doi.org/10.2308/iace-50610

Bell, T. B., \& Griffin, J. B. (2012). Commentary on auditing high-uncertainty fair value estimates. Auditing: A Journal of Practice \& Theory, 31(1), 147-155. http://dx.doi.org/10.2308/ajpt-10172

Benston, G. J. (2006). Fair-value accounting: A cautionary tale from Enron. Journal of Accounting and Public Policy, 25,465-484. http://dx.doi.org/10.1016/j.jaccpubpol.2006.05.003

Betakova, J., Hrazdilova-Bockova, K., \& Skoda, M. (2014). Fair value usefulness in financial statements. DAAAM International Scientific Book., Chapter 35, p. 433-448.

Bonaci, C. G., \& Strouhal, J. (2011). Fair value accounting and the regulation of corporate reporting. Economics \& Management, 16, 14-20.

Bratten, B. P., Gaynor, L. P., McDaniel, L. P., Montague, N. P., \& Sierra, G. P. (2013). The audit of fair values and other estimates: the effects of underlying environmental, task, and auditor-specific factors. Auditing: A Journal of Practice \& Theory, 32(1), 7-44. http://dx.doi.org/10.2308/ajpt-50316

Carroll, T. J., Linsmeier, T. J., \& Petroni, K. R. (2003). The Reliability of Fair Value versus Historical Cost Information: Evidence from Closed-End Mutual Funds. Journal of Accounting, Auditing \& Finance, 18(1), $1-23$.

Chea, A. C. (2011). Fair value accounting: its impacts on financial reporting and how it can be enhanced to provide more clarity and reliability of information for users of financial statements. International Journal of Business and Social Science, 2(20), 12-19.

Clor-Proell, S. M., Proell, C. A., \& Warfield, T. D. (2014). The Effects of Presentation Salience and Measurement Subjectivity on Nonprofessional Investors' Fair Value Judgments. Contemporary Accounting Research, 31(1), 45-66. http://dx.doi.org/10.1111/1911-3846.12041

Cristin, N. T., \& Miticã, P. (2013). Fair Value Versus Historical Cost In Forecast Of Income for Banking Companies. Annals of Faculty of Economics, 1(2), 550-558.

de Jager, P. (2014). Liberal Fair Value Accounting in Banks: A South African Case Study. Australian Accounting Review, 24(2), 134-153. http://dx.doi.org/10.1111/auar.12011 
Devi, R., Devi, J., Kumar, R., \& Taylor, C. (2012). Accountant and User Perceptions of Fair Value Accounting: Evidence from FIJI. Global Journal of Business Research, 6(3), 93-102.

Evans, M. E., Hodder, L., \& Hopkins, P. E. (2014). The Predictive Ability of Fair Values for Future Financial Performance of Commercial Banks and the Relation of Predictive Ability to Banks' Share Prices. Contemporary Accounting Research, 31(1), 13-44. http://dx.doi.org/10.1111/1911-3846.12028

FASB. (2006). FAS 157: Fair Value Measurements. Retrieved from: http://www.fasb.org/jsp/FASB/Page/PreCodSectionPage\&cid=1218220137031\#fas168

FASB. (2007). FAS 159: The Fair Value Option For Financial Assets and Financial Liabilities Including an Amendment of FASB Statement 115 Number Retrieved from: http://www.fasb.org/jsp/FASB/Page/PreCodSectionPage\&cid=1218220137031\#fas168

FASB. (2009). FSP FAS 157-4: Determining Fair Value When the Volume and Level of Activity for the Asset or Liability Have Significantly Decreased and Identifying Transactions That are Not Orderly. Retrieved from: http://www.fasb.org/jsp/FASB/Page/PreCodSectionPage\&cid=1218220137031\#fas168

FASB. (1980). Qualitative Characteristics of Accounting Information. Statement of Financial Accounting Concepts No.2. Retrieved from: http://www.fasb.org/jsp/FASB/Page/PreCodSectionPage\&cid=1176156317989

Fornaro, J. M., \& Barbera, A. T. (2007). The New Fair Value Hierarchy: Key Provisions, Implications, and Effect on Information Usefulness. Review of Business, 28(1), 31-37.

Guthrie, K., Irving, J., \& Sokolowsky, J. (2011). Accounting Choice and the Fair Value Option. Accounting Horizons/ American Accounting Association, 25(3), 487-510. http://dx.doi.org/10.2308/acch-50006

He, X., Wong, T. J., \& Young, D. (2012). Challenges for Implementation of Fair Value Accounting in Emerging Markets: Evidence from China. Contemporary Accounting Research, 29(2), 538-562. http://dx.doi.org/10.1111/j.1911-3846.2011.01113.x

Hitz, J. (2007). The Decision Usefulness of Fair Value Accounting - A theoretical Perspective. European Accounting Review, 16(2), 323-362. http://dx.doi.org/10.1080/09638180701390974

Hlaing, K. P., \& Pourjalali, H. (2012). Economic reasons for reporting property, plant, and equipment at fair market value by foreign cross-listed firms in the United States. Journal of Accounting, Auditing \& Finance, 27(4), 557-576. http://dx.doi.org/10.1177/0148558X11423681

Jaggi, B., Winder, J. P., \& Lee, C. (2010). Is There a Future for Fair Value Accounting After the $2008-2009$ Financial Crisis?.Review of Pacific Basin Financial Markets \& Policies, 13(3), 469-493. http://dx.doi.org/10.1142/S0219091510002037

Jordan, C. E., Clark, S. J., \& Pate, G. R. (2013). The Debate over Fair Value Reporting. CPA Journal, 83(2), 46-51.

Karstetter, E., \& Lien, M. (2009). Tactical Implementation of Fair Value Rules. Financial Executive, 25(10), 30-34.

Kaya, C. T. (2013). Fair Value versus Historical Cost: Which is actually more "Fair"?. Journal of Accounting \& Finance, (60), 127-137.

Kaytmaz Balsari, C., \& Varan, S. (2014). IFRS implementation and studies in Turkey. Accounting \& Management Information Systems, 13(2), 373-399.

Laghi, E., Pucci, S., Tutino, M., \& Di Marcantonio, M. (2012). Fair Value Hierarchy in Financial Instruments Disclosure-Is There Transparency for Investors? Evidence from the Banking Industry. Journal of Governance and Regulation, 1(4), 23- 38.

Landsman, W. R. (2007). Is fair value accounting information relevant and reliable? Evidence from capital market research. Accounting \& Business Research Special Issue: International Accounting Policy Forum, 19-30. http://dx.doi.org/10.1080/00014788.2007.9730081

Laux, C., \& Leuz, C. (2010). Did Fair-Value Accounting Contribute to the Financial Crisis?. Journal of Economic Perspectives, 24(1), 93-118. http://dx.doi.org/10.1257/jep.24.1.93

Laux, C., \& Leuz, C. (2009). The Crisis of Fair-Value Accounting: Making Sense of the Recent Debate. Accounting, Organizations and Society, 34(6-7), 826-34. http://dx.doi.org/10.1016/j.aos.2009.04.003

Leggett, D., Wilkins, A., \& Clark, S. (2015). The frequency, magnitude, and measurement subjectivity associated with liabilities reported at fair value. Academy of Accounting \& Financial Studies Journal, 19(1), 160-170. 
Liao, H. M., Liu, L. L. S., Suvankulov, F., \& Branson, L. (2014, May). Fair value, auditors'specialization and value relevance of financial products. In Global Conference on Business \& Finance Proceedings (Vol. 9, No. 2, pp. 260-267). Institute for Business \& Finance Research.

Lilien, S., Sarath, B., \& Schrader, R. (2013). Normal Turbulence or Perfect Storm? Disparity in Fair Value Estimates. Journal of Accounting, Auditing \& Finance, 28(2), 192-211. http://dx.doi.org/10.1177/0148558X13479693

Linsmeier, T. (2013). A Standard setter's framework for selecting between fair value and historical cost measurement attributes: A basis for discussion of 'Does fair value accounting for nonfinancial assets pass the market test?. Review of Accounting Studies, 18(3), 776-782. http://dx.doi.org/10.1007/s11142-013-9238-7

Magnan, M. L. (2009). Fair Value Accounting and the Financial Crisis: Messenger or Contributor?. Accounting Perspectives, 8(3), 189-213.

Mănoiu, S. M., \& Damian, M. I. (2015). The Impact of Corporate Governance on Fair Value Accounting. Audit Financiar, 13(4/124), 89-96.

Markarian, G. (2014). The crisis and fair values: echoes of early twentieth century debates?. Accounting Historians Journal, 4l(1), 35-60.

Milburn, J. A. (2008). The Relationship between Fair Value, Market Value, and Efficient Markets. Accounting Perspectives, 7(4), 293-316. http://dx.doi.org/10.1506/ap.7.4.2

Miller, P. B., \& Bahnson, P. R. (2007). Refining fair value measurement: FASB 157 upgrades the quality of financial reporting. Journal of Accountancy, 204 (5), 30-36.

Pabuccu, C. (2011). Mark-to-Market Accounting: Guilty or Not?. Journal of Structured Finance, 17(1), 61-75.

Palea, V., \& Maino, R. (2013). Private Equity Fair Value Measurement: A Critical Perspective on IFRS 13. Australian Accounting Review, 23(3), 264-278. http://dx.doi.org/10.1111/auar.12018

Power, M. 2010. Fair Value Accounting, Financial Economics, and the Transformation of Reliability. Accounting and Business Research, 40(3), 197-210. http://dx.doi.org/10.1080/00014788.2010.9663394

Procházka, D. (2011). The role of fair value measurement in the recent financial crunch. Economics, Management \& Financial Markets, 6(1), 989-1001. http://dx.doi.org/10.18267/j.pep.388

Rabin, S. (2009). The Fair Value Compromise- a Proposed Solution. Value Examiner, May/June, 15-17.

Ronen, J. (2008). To Fair Value or Not to Fair Value: A Broader Perspective. Abacus, 44(2), 181-208. http://dx.doi.org/10.1111/j.1467-6281.2008.00257.x

Ronen, J. (2012). What Do FAS 157 "Fair Values" Really Measure: Value or Risk?. Accounting Perspectives, 11(3), 149-164. http://dx.doi.org/10.1111/j.1911-3838.2012.00037.x

Săhlian, D., Botea, M. \& Traşcă, D.L, (2013). Fair value hedging, between opportunity and necessity, Theoretical and Applied Economics, 20 (12/589), 97-104.

Singh, J. P. (2015). Fair Value Accounting: A Practitioner's Perspective. IUP Journal of Accounting Research \& Audit Practices, 14(2), 53-65.

Smith, S. R., \& Smith, K. R. (2014). The journey from historical cost accounting to fair value accounting: The case of acquisition costs. Journal of Business \& Accounting, 7(1), 3-10.

Strampelli, G. (2011). The IAS/IFRS after the crisis: limiting the impact of fair value accounting on companies' capital. European Company \& Financial Law Review, 8(1), 1-29. http://dx.doi.org/10.1515/ecfr.2011.1

Taplin, R., Yuan, W., \& Brown, A. (2014). The Use of Fair Value and Historical Cost Accounting for Investment Properties in China. Australasian Accounting Business \& Finance Journal, 8(1), 101-113. http://dx.doi.org/10.14453/aabfj.v8i1.6

Valencia, A., Smith, T. J., \& Ang, J. (2013). The Effect of Noisy Fair Value Measures on Bank Capital Adequacy Ratios. Accounting Horizons, 27(4), 693-710. http://dx.doi.org/10.2308/acch-50517

Wier, H. A. (2009). Fair Value or Conservatism: The Case of the Gold Industry. Contemporary Accounting Research, 26(4), 1207-1233. http://dx.doi.org/10.1506/car.26.4.8

Wallison, P. J. (2008). Fair value accounting: A critique. American Enterprise Institute for Public Policy Research, Financial Services Outlook, July. 
Yamamoto, T. (2014). Fair value of investment property and independent appraisers: the experience in the UK and Japan. The Appraisal Journal, Spring (2), 138-154.

\section{Notes}

Note 1. When market price is used to determine the fair value of element, fair value accounting called Mark-to-market accounting (Laux \& Leuz, 2010, p. 93) which, "refers to the accounting standards of assigning a value to a position held in a financial instrument based on the current fair market price, rather than its original cost or book value, for the instrument or similar instruments" (Chea, 2011, p. 13). That is, "the pure form of fair value accounting is mark-to-market accounting under which entities measure the values by using unadjusted market prices" (Pabuccu, 2011, p. 63).

Note 2. An active market for an element, "is a market in which transactions for the asset or liability occur with sufficient frequency and volume to provide pricing information on an ongoing basis" (FASB, 2006, para.24, p. FAS 157-12).

Note 3. Observable inputs, "reflect assumptions that market participants would make, based upon market-based information from sources independent of the company" (Fornaro and Barbera, 2007, p. 32).

Note 4. More details about SFAS 157 methodology can also be found, for example, at Fornaro and Barbera (2007); Miller and Bahnson (2007) and Ronen (2012).

Note 5. Current replacement cost or cost approach is, "the amount that currently would be required to replace the service capacity of an asset" (FASB, 2006, para. 18/C, p. FAS 157-11).

Note 6. IAS 39 was superseded by IFRS 9 "Financial Instruments" where IFRS 9 is applied.

Note 7. In case that market price not found, entities are allowed to use their own estimation approach called "mark to model approach" (Pabuccu, 2011).

Note 8. According to Ronen (2012, p. 149) exit values are, "the proceeds for assets hypothetically sold on the date of the financial report, and, correspondingly, the amount required to settle liabilities on the date of the financial report". 